
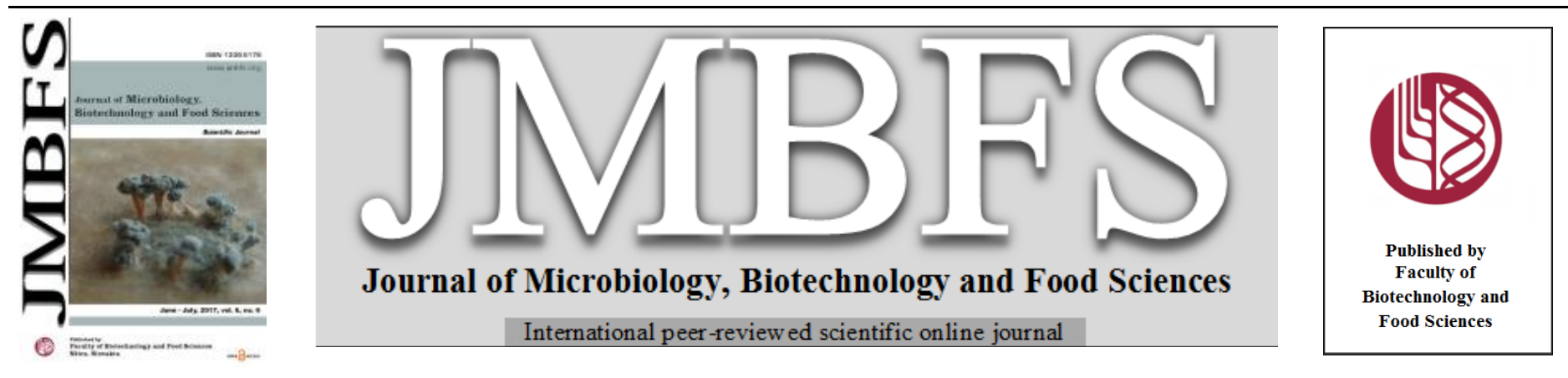

\title{
CHARACTERIZATION AND ISOLATION OF PEPTIDE METABOLITES OF AN ANTIFUNGAL BACTERIAL ISOLATE IDENTIFIED AS BACILLUS AMYLOLIQUEFACIENS SUBSPECIES PLANTARUM STRAIN FZB42
}

\author{
Abiodun Adibi ${ }^{1 *}$,Evan R. Rees ${ }^{2}$, Saudia McCarley ${ }^{1 \#}$, Vincent P. Sica ${ }^{2}$ and Nicholas H. Oberlies ${ }^{2}$ \\ $\operatorname{Address(es):~}$ \\ ${ }^{1}$ Department of Biological Sciences, Hampton University, Hampton, VA 23668 USA 757-727-5017. \\ ${ }^{2}$ Department of Chemistry and Biochemistry, University of North Carolina at Greensboro, Greensboro, NC 27402 USA. \\ "Meharry Medical College, Nashville, TN 37208 USA. \\ *Corresponding author: Abiodun.Adibi@hamptonu.edu
}

doi: 10.15414/jmbfs.2017.6.6.1309-1313

ARTICLE INFO

Received 22. 5. 2016

Revised 22. 4. 2017

Accepted 13. 5. 2017

Published 1. 6. 2017

Regular article

open $O$ access

\begin{abstract}
Some bacteria produce antimicrobial chemicals in their immediate environments. These antimicrobial agents are enzymes, polypeptides or non-protein organic compounds. In this study, a bacterial isolate that produces antifungal chemical(s) was isolated from an over incubated nutrient agar plate that was exposed to air. The bacterium is aerobic, Gram positive bacilli; capsule and endospore producing. It ferments glucose and sucrose but not lactose, galactose, mannitol and sorbitol; it is citrate, indole, methyl red and Voges Prauskauer negative. Using agar gel diffusion technique, the cell-free culture supernatant resulting from centrifugation of a six day bacterial culture showed antifungal activity against filamentous fungi but not yeasts. Heating the cell-free supernatant in $90{ }^{\circ} \mathrm{C}$ water bath and digestion with different proteases had no negative impact on the antifungal activity. A segment of $16 \mathrm{~S}$ rRNA gene of the bacterial isolate was amplified. The nucleotide sequence of the amplicon was used to identify the bacterium as being very similar to Bacillus amyloliquefaciens subsp. plantarum strain FZB42. Five bacterial peptides were isolated and identified from cell free supernatant of the bacterial culture using a suite of techniques, including flash chromatography, HPLC, NMR and mass spectrometry. One of the five peptides has been previously reported in literature to possess antifungal activity.
\end{abstract}

Keywords: Antifungal; Bacillus amyloliquefaciens; peptide metabolites; preparative HPLC

\section{INTRODUCTION}

Different types of bacteria are sources of industrial enzymes and compounds that have antifungal or antibacterial properties. In a study of 1200 isolates of lactic acid bacteria by Magnusson et al. (2003), 37 isolates showed inhibitory activity against different types of filamentous fungi and against the yeast Rhodotorula mucilaginosa. According to several studies, antifungal agents are produced by various species of Bacillus. In 2014, Oyedele et al. isolated Bacillus subtilis, B. megaterium, B. licheniformis and B. pumilus from different food sources. Nine strains of the isolated $B$. subtilis showed antifungal activities against a variety of filamentous fungi. Some of the other studies that showed antifungal activities of Bacillus species include Islam et al., 2012 (Bacillus subtilis); Munimbazi and Bullerman, 1998 (Bacillus pumilus); Qazi et al., 2009 and Pleban et al., 1997 (B. cereus ); Tendulkar et al., 2007, Trachuk et al., 1996 and Takayanagi et al., 1991 (B. licheniformis); Watanabe et al., 1990 (B. circulans). Other bacterial genera have also been reported to produce antifungal chemicals. As was reported by Fguira et al., 2005 and Rhee, Ki-Hyeong, 2003, filamentous soil bacteria belonging to the genus Streptomyces exhibited antifungal and antibacterial activities resulting from production of non-protein compounds. Lavermicocca et al. (2000) isolated novel antifungal compounds from Lactobacillus plantarum associated with sourdough. Similarly, Chernin et al. (1995) showed that Enterobacter agglomerans, a soil-borne bacterium, was antagonistic to many plant fungi as a result of production of chitinolytic enzymes that hydrolyse fungal cell wall. The antifungal agents produced by different bacterial isolates were characterized (Qazi et al., 2009) or isolated, purified and characterized (Fguira et al., 2005; Lavermicocca et al., 2000). Most of the purified antifungal agents in the studies are polypeptides; some are chitinolytic enzymes while others are non-protein compounds, each with different properties. Such antifungal agents have potential uses in agriculture where they could serve as alternatives to chemical fungicides that are used to prevent plant fungal diseases of agricultural products and plants. Purified antifungal agents also have potential uses in cell culture and as food preservatives.

In the current study, nutrient agar plates were exposed to air and incubated at room temperature. One of these plates was overgrown with a filamentous fungus except around a bacterial colony where there was inhibition of fungal growth (Figure 1). The aims of this study are to characterize and identify the antifungal bacterial isolate and also the antifungal chemical produced by the bacterial isolate.

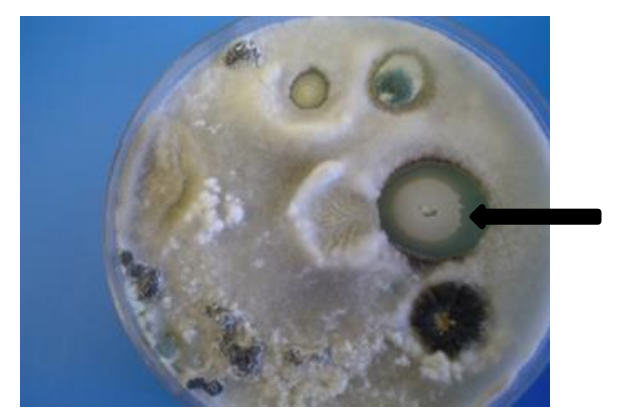

Figure 1 Nutrient agar plate showing a bacterial colony with antifungal activity indicated by a clear zone around the bacterial colony (arrow).

\section{MATERIALS AND METHODS}

Initial screening of efficacy of bacterial antifungal activity

The antifungal bacterium was subcultured on LB agar to obtain a pure culture. The efficacy of the bacterial isolate on fungal growth was done using agar diffusion method. Sabouraud dextrose agar plates were prepared and separate plates were inoculated with a wild yeast, Candida albicans and different types of filamentous fungi; the plates were incubated at $25 \mathrm{C}$. When fungal growth was evident on each of the plates, the bacterial isolate was then inoculated approximately one inch directly opposite the fungal growth; the plates were incubated further. 


\section{Characterization of bacterial antifungal chemical}

The bacterial isolate was inoculated into $500 \mathrm{ml}$ of LB broth and incubated at 25 ${ }^{\circ} \mathrm{C}$ in a shaker incubator. Cell free supernatant was obtained by centrifugation of the culture in a Beckman Model J2-21centrifuge using JA 14 rotor. The supernatant was further filtered using $0.45 \mu \mathrm{M}$ Nalgene disposable membrane filter ware. The resulting cell-free supernatant was stored at $4 \mathrm{C}$. Antifungal activity of the supernatant was determined using agar gel diffusion method.

The effect of temperature on the efficacy of the antifungal agent was carried out by incubating the cell-free supernatant at $40{ }^{\circ} \mathrm{C}, 50{ }^{\circ} \mathrm{C}, 70{ }^{\circ} \mathrm{C}$ and $90{ }^{\circ} \mathrm{C}$ for 30 minute. This was followed by efficacy test against filamentous fungus using agar gel diffusion.

Effect of enzyme treatment on the antifungal agent was done. The enzymes used were lipase, protease, proteinase $\mathrm{K}$, pepsin and chymotrypsin. Culture supernatant was subjected to enzyme treatments for $1 \mathrm{hr}$ in a $37{ }^{\circ} \mathrm{C}$ water bath after which the enzyme was inactivated prior to determining the efficacy of the product on fungal growth. Efficacy was determined using agar gel diffusion method as stated earlier.

\section{Morphological and biochemical characterization of the antifungal agent- producing bacterial isolate}

Morphological characteristics of the bacterial isolate were determined using routine microbiological tests including Gram stain, endospore stain, capsule stain and motility test. Biochemical characterization of the bacterial isolate included the following tests: fermentation of different sugars, catalase production, oxidase test, MR-VP test, oxygen requirement test using fluid thioglycollate broth, indole production, citrate utilization, and production of exoenzymes for hydrolysis of starch, protein and lipid. All the microbiological tests were performed as are described by Leboffe and Pierce (2008).

\section{Identification of bacterial isolate}

The bacterial isolate was identified by amplification and sequencing of segment of 16S rRNA gene using colony PCR and universal primers F-27 5' AGAGTTTGATCMTGGCTCAG-3' and R1525 5' AAGGAGGTGWTCCARCC-3'. The PCR conditions were denaturation at 94 ${ }^{\circ} \mathrm{C}$ for $5 \mathrm{~min}$; 30 cycles: $94{ }^{\circ} \mathrm{C}$ for $30 \mathrm{sec}, 55{ }^{\circ} \mathrm{C}$ for $30 \mathrm{sec}, 72{ }^{\circ} \mathrm{C}$ for $1.5 \mathrm{~min}$; final extension at $72{ }^{\circ} \mathrm{C}$ for $10 \mathrm{~min}$. The PCR product was cloned into TA cloning vector following the manufacturer's protocol; this was followed by transformation. Recombinant plasmids were prepared from selected transformants using Qiagen Mini Plasmid Preparation kit and were quantitated using NanoDrop Spectrophotometer, ND-1000. DNA sequencing was done by Integrated DNA Technologies, Inc. The nucleotide sequence obtained was used to identify the bacterial isolate using the National Center for Biotechnology Information (NCBI) genomic BLAST.

\section{Purification of antifungal metabolites}

An extraction of the cell-free supernatant was performed by adding $\mathrm{CHCl}_{3}$ $\mathrm{CH}_{3} \mathrm{OH}$ (4:1). The mixture was stirred for $30 \mathrm{~min}$ and then transferred to a separating funnel. The bottom layer was drawn off and evaporated to dryness The resulting organic component was further extracted with equal volume of $\mathrm{CH}_{3} \mathrm{OH}-\mathrm{CH}_{3} \mathrm{CN}$ and hexanes; the two layers were drawn off, evaporated to dryness under vacuum and the dried extracts were weighed. This was followed by flash chromatography of the $\mathrm{CH}_{3} \mathrm{OH}-\mathrm{CH}_{3} \mathrm{CN}$ extract. The extract was dissolved in $\mathrm{CHCl}_{3}$ and transferred onto celite and allowed to dry. The celite was transferred and packed in a chromatography cartridge. At a $18 \mathrm{~mL} / \mathrm{min}$ flow rate, a solvent gradient of $100 \%$ hexane to $100 \% \mathrm{CHCl}_{3}$ to $100 \% \mathrm{CH}_{3} \mathrm{OH}$ was flowed through the chromatography cartridge over $28 \mathrm{~min}$. The sample was pooled into three fractions and evaporated to dryness. Fraction 2 was dissolved in 1:1 $\mathrm{CH}_{3} \mathrm{OH}$-dioxane and subjected to preparative HPLC. The mobile phase was a gradient of $\mathrm{CH}_{3} \mathrm{CN}-\mathrm{H}_{2} \mathrm{O}$ with $0.1 \%$ formic acid. The gradient flowed at $15-20 \%$ $\mathrm{CH}_{3} \mathrm{CN}$ over $15 \mathrm{~min}$ to $20 \%$ isocratic $\mathrm{CH}_{3} \mathrm{CN}$ over $20 \mathrm{~min}$ at a $15 \mathrm{~mL} / \mathrm{min}$ flow rate. The column used was an Atlantis Prep, OBD 19x250 mm column, No. 186004026. This yielded five isolated compounds.

\section{Identification of antifungal metabolites}

High resolution mass spectrometry (HRMS) was performed using a QExactive Plus (Thermo Fisher Scientific, San Jose, CA, USA). Resolution was 70,000, and MS/MS was performed with higher energy collisional dissociation (HCD) at 52.50. Additionally, the ${ }^{1} \mathrm{H}$ NMR (400 MHz; JEOL Ltd., Tokyo, Japan) was performed on the isolated compounds to confirm the structures.

\section{RESULTS}

\section{Screening and characterization of antifungal metabolite}

Streak of the bacterial isolate opposite Candida albicans and filamentous fung showed that the antifungal metabolite secreted into the culture medium inhibited only filamentous fungi. Figure 2 shows inhibition of a filamentous fungus by the bacterial isolate after incubation of the plate for four days. Cell-free supernatant obtained from centrifugation of the antifungal bacterial isolate in LB broth also showed growth inhibition of filamentous fungi (Figure 3). The results of heat treatment of the cell-free, culture supernatant showed that the antifungal metabolite is heat stable because the efficacy of the culture supernatant was not abrogated by the treatments (Figure 4). Treatment of the cell-free supernatant with the enzymes used in the studies produced no negative effect on the efficacy against filamentous fungi.

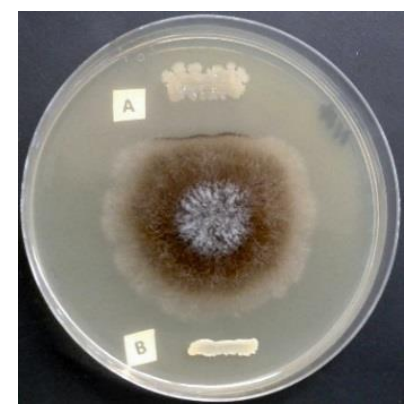

Figure 2. Inhibition of fungal growth after four day incubation at room temperature. Inhibition is shown as a straight line, by the antifungal bacterial isolate " $\mathrm{A}$ " inoculated on one side of fungal culture. Bacterium " $\mathrm{B}$ " is a non antifungal agent producing bacterium.

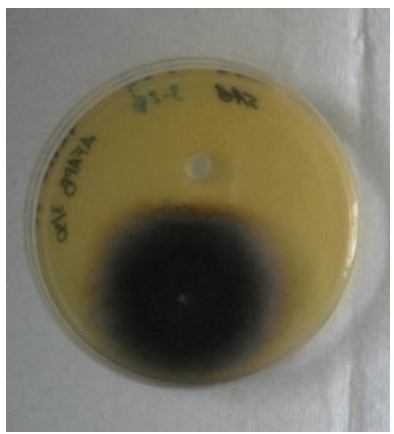

Figure 3. Sabouraud dextrose agar plate after two day incubation showing slight inhibition of filamentous fungal growth adjacent to a well that was filled with cell-free supernatant from the antifungal bacterial isolate culture. The inhibition is shown as a straight line and a decrease in the periphery of the fungal growth.

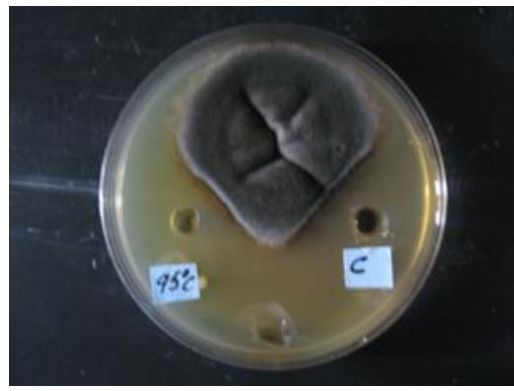

Figure 4. Inhibition of fungal growth opposite wells filled with cell-free culture supernatants (heated at $95{ }^{\circ} \mathrm{C}$ for $30 \mathrm{~min}$ and untreated control "C"). The plate was incubated at room temperature for more than 8 days during which the supernatants in the two wells were replenished several times. At the bottom of the plate is not a well but an accidental agar chip.

\section{Morphological and biochemical characterization of antifungal bacterial isolate}

The results of morphological and biochemical tests of the bacterial isolate are shown in Table I. The biochemical tests were carried out after approximately 24 48 hour incubation. 
Table 1 Morphological and biochemical characteristics of the antifungal bacterial isolate.

\begin{tabular}{ll}
\hline Tests & Results \\
\hline Gram Stain & Gram positive, bacilli \\
Endospores stain & Oval and centrally located \\
Capsule stain & Positive \\
Motility & Positive \\
Oxygen utilization & Aerobic \\
Catalase & Positive \\
Oxidase & Positive \\
Citrate utilization & Negative \\
Indole production & Negative \\
Methyl red & Negative \\
Voges Proskauer & Negative \\
Hydrolysis of: & \\
Starch & Positive \\
Protein & Positive \\
Lipid & Negative \\
DNA & Positive \\
Fermentation of: & \\
Glucose & Positive \\
Sucrose & Positive \\
Lactose & Negative \\
Galactose & Negative \\
Mannitol & Negative \\
Sorbitol & Negative \\
\hline
\end{tabular}

\section{Identification of bacterial isolate.}

A segment of 16S rRNA was amplified using universal primers F21 and R1525. The nucleotide sequence (1541 nucleotides) of the amplified segment of $16 \mathrm{~S}$ rRNA gene of the bacterial isolate is shown in Figure 5. The DNA sequence was compared with NCBI gene bank database using BLAST algorithm. The result showed a 99\% homology of the search sequence with Bacillus amyloliquefacien subsp. plantarum strain FZB42. The nucleotide sequence was deposited in GenBank under accession number SUB1340497 AF-1 KU738862.

AAGGAGGTGATCCAGCCGCACCTTCCGATACGGCTACCTTGTACGACTTCACCCCAATCATCTGTCCCACCTTCGG CGGCTGGCTCCTAAAAGG ITACCTCACCGACTTCGGGTGTTACAAACTCTCGTGGTGTGACGGGCGGTGTGTACA AGGCCCGGGAACGTATTCACCGCGGCATGCTGATCCGCGATTACTAGCGATTCCAGCTTCACGCAGTCGAGTTGC AGACTGCGATCCGAACTGAGAACAGATTTGTGGGATGGCTTAACCTCGCGGTTTCGCTGCCCTTTGTCTGTCCAT TGTAGCACGTGTGTAGCCCAGGTCATAAGGGGCATGATGATTTGACGTCATCCCCACCTTCCTCCGGITTGTCACC GGCAGTCACCTTAGAGTGCCCAACTGAATGCTGGCAACTAAGATCAAGGGTTGCGCTCGTTGCGGGACTTAACCC AACATCTCACGACACGAGCTGACGACAACCATGCACCACCTGTCACTCTGCCCCCGAAGGGGACGTCCTATCTCTA GGATTGTCAGAGGATGTCAAGACCTGGTAAGGTTCTTCGCGTTGCTTCGAATTAAACCACATGCTCCACCGCTTGT GCGGGCCCCCGTCAATTCCTTTGAGTTTCAGTCTTGCGACCGTACTCCCCAGGCGGAGTGCTTAATGCGTTAGCTG CAGCACTAAGGGGCGGAAACCCCCTAACACTTAGCACTCATCGITTACGGCGTGGACTACCAGGGTATCTAATCCT GITCGCTCCCCACGCTITCGCTCCTCAGCGTCAGTTACAGACCAGAGAGTCGCCTTCGCCACTGGTGTTCCTCCACA TCTCTACGCATTTCACCGCTACACGTGGAATTCCACTCTCCTCTTCTGCACTCAAGTTCCCCAGTITCCAATGACCCT CCCCGGTTGAGCCGGGGGCTTTCACATCAGACTTAAGAAACCGCCTGCGAGCCCTITACGCCCAATAATTCCGGAC AACGCTTGCCACCTACGTATTACCGCGGCTGCTGGCACGTAGTTAGCCGTGGCTTTCTGGTTAGGTACCGTCAAGG TGCCGCCCTATTTGAACGGCACTTRTTCTTCCCTAACAACAGAGCTTTACGATCCGAAAACCTTCATCACTCACGCG GCGTTGCTCCGTCAGACTTTCGYCCATTGCGGAAGATTCCCTACTGCTGCCTCCCGTAGGAGTCTGGGCCGTGTCTC AGTCCCAGTGTGGCCGATCACCCTCTCAGGTCGGCTACGCATCGTCGCCTTGGTGAGCCGTIACCTCACCRACTAG CTAATGCGCCGCGGGTCCATCTGTAAGTGGTAGCCGAAGCCACCTITATGTCTGAACCATGCGGITCARACAACC ATCCGGTATTAGCCCCGGTTTCCCGGAGTTATCCCAGTCTTACAGGCAGGTIACCCACGTGTTACTCACCCGTCCGC CGCTAACATCAGGGAGCAAGCTCCCATCTGTCCGCTCGACTTGCATGTATTAGGCACGCCGCCAGCGTTCGTCCTG AGCCATGATCAAACTCT

Figure 5 Consensus nucleotide sequence of the amplified segment of 16S rRNA gene of the antifungal bacterial isolate

\section{Purification and identification of antifungal metabolites}

The $\mathrm{CHCl}_{3}-\mathrm{CH}_{3} \mathrm{OH}$ extract from the cell-free supernatant yielded $280 \mathrm{mg}$. Flash chromatography on this extract produced three fractions that weighed $0.20 \mathrm{mg}$, $19 \mathrm{mg}$ and $220 \mathrm{mg}$. While fraction three had the largest yield, analytical HPLC revealed that it primarily contained sugars not shown). Therefore only fraction 2 was pursued further, which led to the isolation of compounds 1-5. These compounds were tentatively identified using high resolution and tandem mass spectrometry (Table 2). The structures of the compounds were then confirmed using ${ }^{1} \mathrm{H}$ NMR (Figures S1 \{Supplement 1 \} through S5 \{Supplement 5 \}). All of the isolated compounds were small cyclic peptides (Figure 6); the characterization data for each compound were in good agreement with the literature (Chen et al., 2009; Nakamura et al., 2006; Stark and Hofmann, 2005).
Table 2 High resolution mass spectrometry (HRMS) and MS/MS data of the isolated compounds.

\begin{tabular}{llll}
\hline \multicolumn{2}{l}{ Compound } & \multicolumn{2}{c}{ MS/MS Fragments } \\
\cline { 2 - 3 } & Measured & Calculated & \\
\hline 1 & 195.1128 & 195.1128 & $195,98,70$ \\
\hline 2 & 197.1284 & 197.1285 & $197,169,154,141,124,100,98,72,70$ \\
\hline 3 & 211.1440 & 211.1441 & $211,183,154,138,114,98,86,70$ \\
\hline 4 & 211.1440 & 211.1441 & $211,183,154,138,114,98,86,70$ \\
\hline 5 & 245.1284 & 245.1285 & $245,217,172,154,120,98,70$ \\
\hline
\end{tabular}

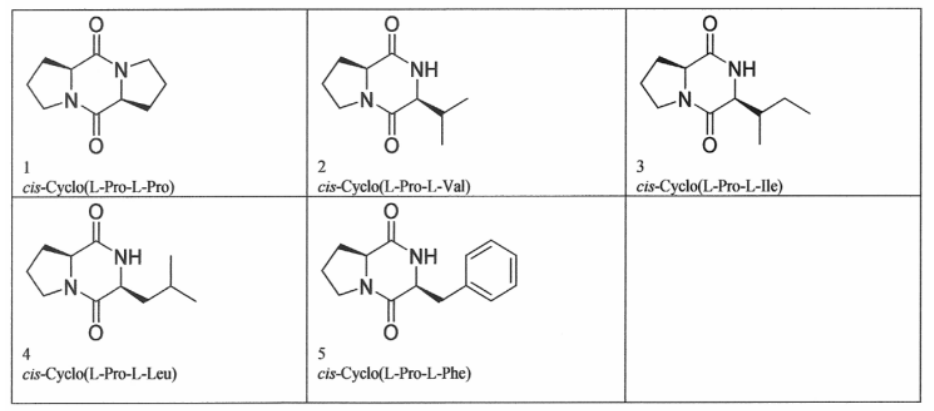

Figure 6 Structures of the five isolated metabolites of Bacillus amyloliquefaciens subspecies plantarum strain FZB42.

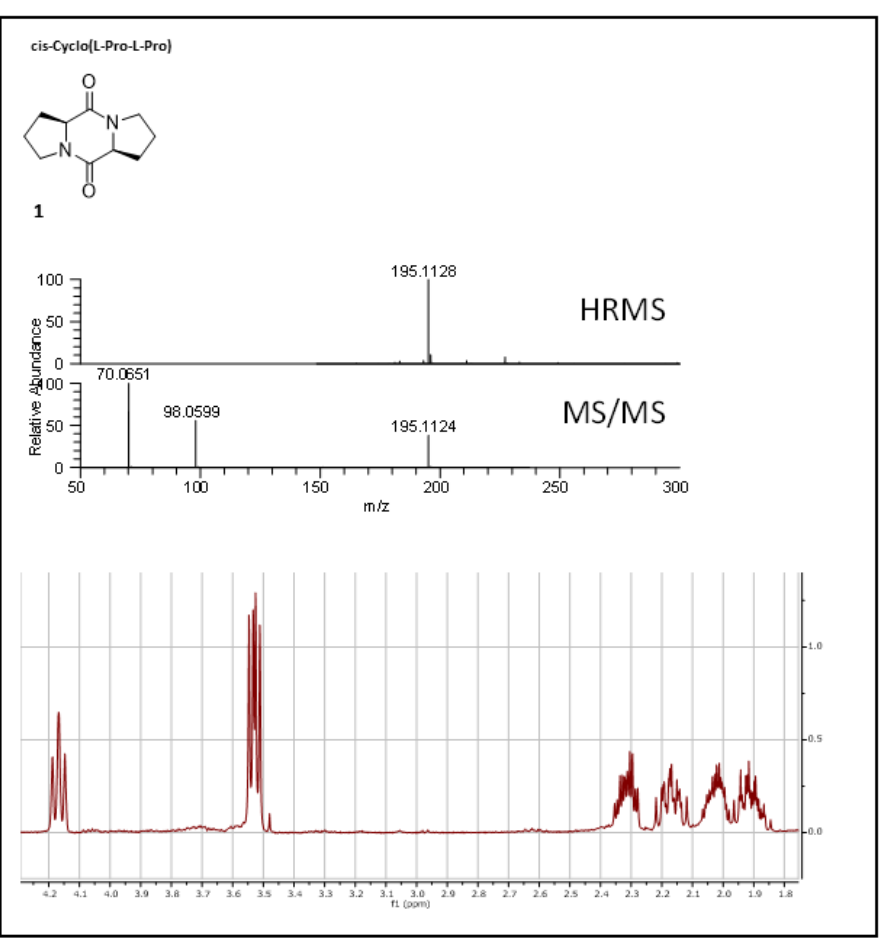

Figure S1 The structure of cis-Cyclo(L-Pro-L-Pro) (1) with the MS/MS fragmentation $(\mathrm{HCD}=52.5)$ and $1 \mathrm{H} \mathrm{NMR}(\mathrm{CDCl} 3,400 \mathrm{MHz})$. 


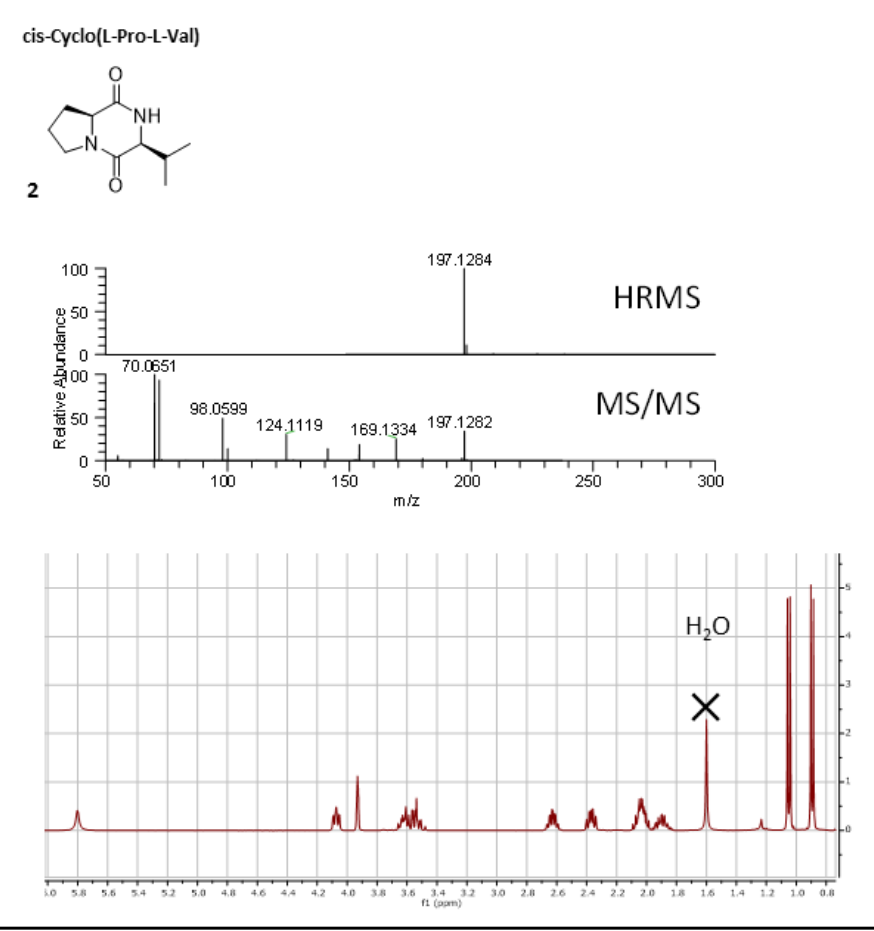

Figure S2 The structure of cis-Cyclo(L-Pro-L-Val) (2) with the MS/MS fragmentation $(\mathrm{HCD}=52.5)$ and $1 \mathrm{H} \mathrm{NMR}(\mathrm{CDCl} 3,400 \mathrm{MHz})$.

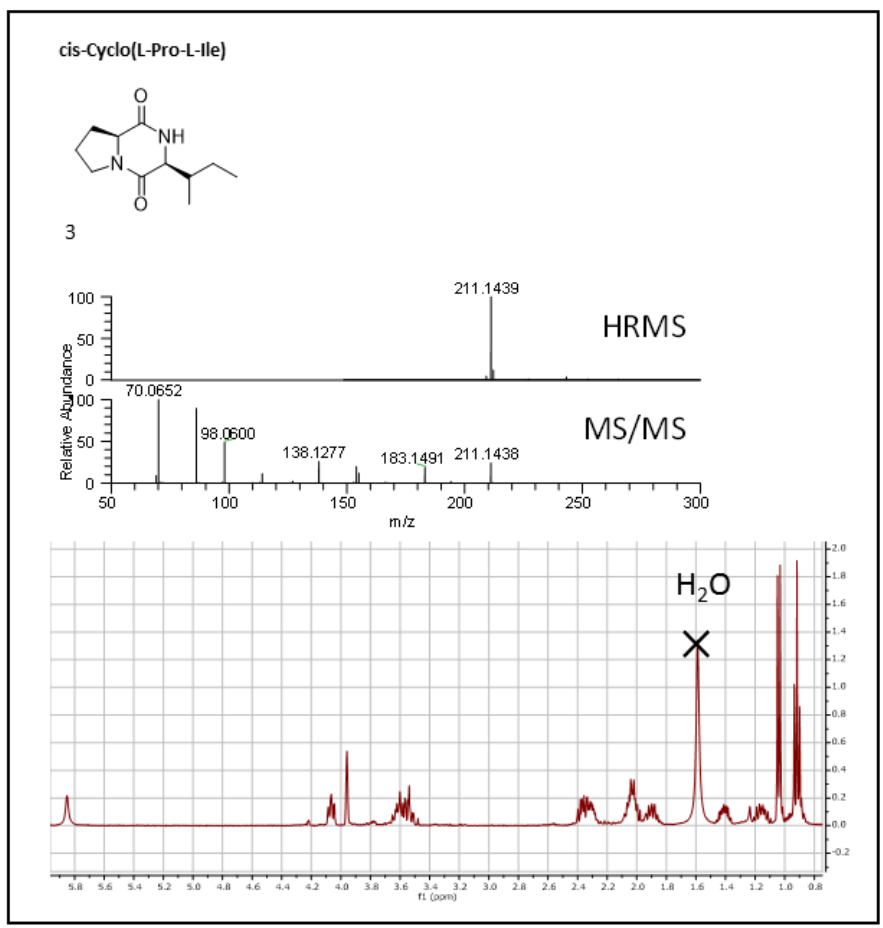

Figure S3 The structure of cis-Cyclo(L-Pro-L-Ile) (3) with the MS/MS fragmentation $(\mathrm{HCD}=52.5)$ and $1 \mathrm{H} \mathrm{NMR}(\mathrm{CDCl} 3,400 \mathrm{MHz})$.

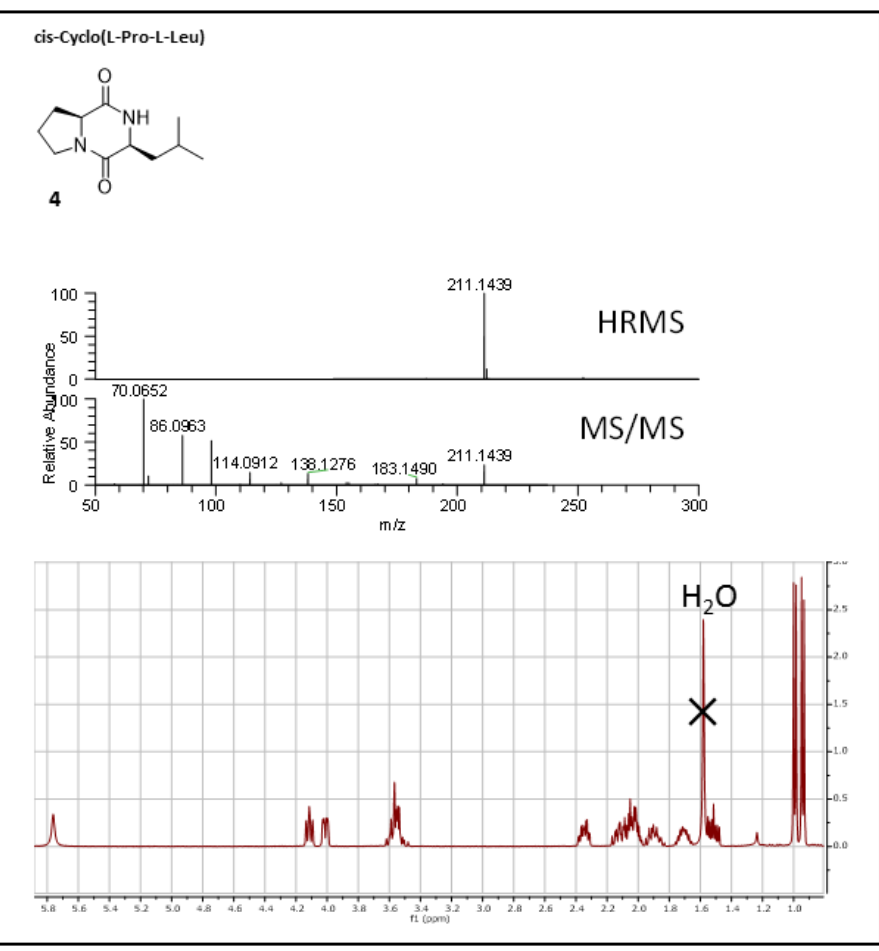

Figure S4 The structure of cis-Cyclo(L-Pro-L-Leu) (4) with the MS/MS fragmentation $(\mathrm{HCD}=52.5)$ and $1 \mathrm{H} \mathrm{NMR}(\mathrm{CDCl} 3,400 \mathrm{MHz})$.

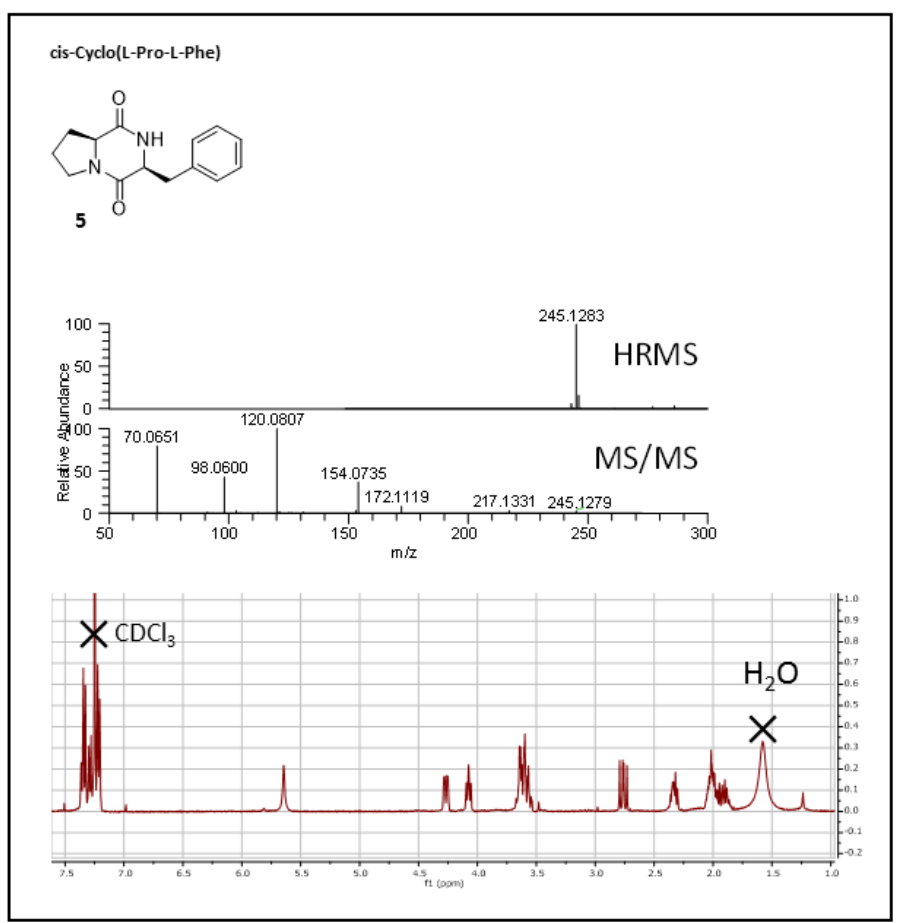

Figure S5 The structure of cis-Cyclo(L-Pro-L-Phe) (5) with the MS/MS fragmentation $(\mathrm{HCD}=52.5)$ and $1 \mathrm{H} \mathrm{NMR}(\mathrm{CDCl} 3,400 \mathrm{MHz})$.

\section{DISCUSSION}

Microorganisms in different environments are in constant competition with each other for nutrients and other materials. As a result, some bacteria produce bacteriocins that inhibit or kill other bacteria species while some produce fungicidal or fungistatic metabolites. Similarly, some fungi produce antibacterial chemicals. According to Meena and Kanwar (2015), "Bacillus genus is considered as the factories for the production of biologically active molecules that are potential inhibitors of growth of phytopathogens". This statement by Meena and Kanwar is supported by the current study and by the studies conducted by Zhao et al. (2013), Beric et al. (2012), Chen (2012), Islam et al. (2012) and Nair et al. (2002). Bacteria produce antifungal metabolites that include different types of peptides (Meena and Kanwar, 2015; DeLucca and 
Walsh, 2000). In their study, Munimbazi and Bullerman (1998) reported that an isolate of Bacillus pumilus from a sample of dried fish was the source of an antifungal agent. Two different studies showed that Bacillus amyloliquefaciens GAI (Arguelles-Arias et al., 2009) and Bacillus amyloliquefaciens LJ02 (Li et al., 2015) produced secondary metabolites for the biocontrol of plant pathogen and for cucurbits powdery mildew, respectively. The antifungal activity of $B$. amyloliquefaciens GAI was due to cyclic lipopeptides surfactin, iturin A and fengycin. The antifungal agent produced by the bacterial isolate, Bacillus amyloliquefaciens subsp. plantarum strain FZB42, in the current study is similar to that produced by B. pumilus (Munimbazi and Bullerman, 1998) in their inhibitory effect on filamentous fungi and not yeasts, resistance to heat treatment and resistance to denaturation by hydrolytic enzymes. However, unlike the current study where the bacterial antifungal agent was isolated and identified, Munimbazi and Bullerman did not identify the antifungal agent. In this study, five cyclic dipeptides were isolated from cell-free, culture supernatant of Bacillus amyloliquefaciens subsp. plantarum strain FZB42. The five peptides were identified as: cis-Cyclo(L-Pro-L-Pro) (1), cis-Cyclo(L-Pro-L-Val) (2), cisCyclo(L-Pro-L-Ile) (3), cis-Cyclo(L-Pro-L-Leu) (4) and cis-Cyclo(L-Pro-L-Phe) (5). This report that cyclic peptide is responsible for antifungal activity the bacterial isolate is supported by Magnusson et al. (2003); the group reported that the antifungal activity of Lactobacillus coryniformis strain Si3 could be due to Cyclo(phe-Pro) and Cyclo(Phe-4-OH-Pro) that were identified from bacterial culture supernatant. While one of these five peptides, cis-Cyclo(L-Pro-L-Val) (2) in the current study was previously reported to have an antifungal effect, the roles of the other four metabolites are not exactly known. Purified antifungal peptides could be a better alternative to the use of whole bacterial cells as inhibitors of fungal phytopathogens. The biological active, antifungal peptide could also find uses in the food industries as preservatives, in cell culture and in treating human dermatophytes.

\section{CONCLUSION}

It can be concluded that this study supports previous findings that members of the genus Bacillus produce antifungal agents. The bacterial isolate that was identified as Bacillus amyloliquefaciens subspecies plantarum strain FZB42 produces five peptide metabolites; at least one of these peptide metabolites (cis-Cyclo(L-Pro-LVal) is a known and unique antifungal agent that is resistant to high temperature and hydrolytic enzymes. Future work is to synthesize: cis-Cyclo(L-Pro-L-Pro) (1), cis-Cyclo(L-Pro-L-Ile) (3), cis-Cyclo(L-Pro-L-Leu) (4) and cis-Cyclo(L-ProL-Phe) (5) and study their efficacy against fungi and bacteria.

Acknowledgements: The authors are grateful to Dr. Indu Sharma of Hampton University for her assistance with nucleotide sequence analysis and GenBank submission. We also thank Tyler Graf at the University of North Carolina, Greensboro for assistance in the chromatographic techniques and Dr. Guijun Wang at Old Dominion University Department of Chemistry and Biochemistry, for her input and advise that made this work a reality.

\section{REFERENCES}

ARGUELLES-ARIAS, A., ONGENA, M., HALIMI, B., LARA, Y., BRANS, A., JORIS, B., \& FICKERS, P. 2009. Bacillus amyloliquefaciens GAI as a source of potent antibiotics and other secondary metabolites for biocontrol of plant pathogens. Microbial Cell Factories 8:63. http://dx.doi.org/10.1186/1475-2859-8 63

BERIC, T., KOJIC, M., STANKOVIC, S., TOPISIROVIC, L., DEGRASSI, G. MYERS, M., VENTURI, V., FIRA, D. 2012. Antimicrobial activity of Bacillus sp. Natural isolates and their potential use in the biocontrol of phytopathogenic bacteria. Food Tech. Biotechnol. 50:25-31

CHEN, M.Z., DEWIS, M.L., KRAUT, K., MERRITT, D., REIBER, L., TRINNAMAN, L., AND DA COSTA, N.C. (2009). 2, 5-diketopiperazines (cyclic dipeptides) in beef: Identification, synthesis, and sensory evaluation. J. Food Sci. 74, C100-105. http://dx.doi.org/ 10.1111/j.1750-3841.2009.01062.x

CHEN, N., JIN, M., QU, H., CHEN, Z., CHEN, Z., QIU, Z., WANG, X., \& LI, J. 2012. Isolation and characterization of Bacillus sp. producing broad-spectrum antibiotics against human and plant pathogenic fungi. J. Microbiol. Biotechnol. 22(2): 256-263. http://dx.doi.org/10.4014/jmb.1107.07021

CHERNIN, L., ISMILOV, Z., HARAN, S., \& CHET, I. 1995. Chitinolytic Enterobacter agglomerans antagonistic to fungal plant pathogens. Appl. Environ Microbiol. 61(5):1720-1726.

DE LUCCA, A. J., \& WALSH, T.J. 2000 Antifungal peptides: Origin, activity, and therapeutic potential. Rev Iberoam Micol 17: 116-120.

FGUIRA, L.F., FOTSO, S., AMEUR-MEHDI, R.B., MELLOULI, L., \& LAATSCH, H. 2005. Purification and structure elucidation of antifungal and antibacterial activities of newly isolated Streptomyces sp. strain US80. Research in Microbiol. 156:341-347. http://dx.doi.org/10.1016/j.resmic.2004.10.006

ISLAM, MD. R, JEONG, Y.T., LEE, Y.S. \& SONG, C.H. 2012. Isolation and identification of antifungal compounds from Bacillus subtilis $\mathrm{C} 9$ inhibiting the growth of plant pathogenic fungi. Mycobiology 40(1): $59-66$ http://dx.doi.org/10.5941/MYCO.2012.40.1.059
LAVERMICOCCA, P., VALERIO, F., EVIDENTE, A., LAZZARONI, S., CORSETTI, A., \& GOBBETT, M. (2000). Purification and characterization of novel antifungal compounds from the sourdough Lactobacillus plantarum Strain 21B. Appl. Environ Microbiol. 66(9):4084-4090 http://dx.doi.org/10.1128/AEM.66.9.4084-4090.2000

LEBOFFE, M.J. AND PIERCE, B.E. (2012). Microbiology Laboratory theory and application. $2^{\text {nd }}$ Edition. Morton Publishing Company. Englewood, CO.

LI Y., GU, Y., LI, J., XU, M., WEI, Q., \& AND WANG, Y. 2015. Biocontrol agent Bacillus amyloliquefaciens LJ02 induces systemic resistance against cucurbits powdery mildew. Frontiers in Microbiol. 6:883. http://dx.doi.org/ 10.3389/fmicb.2015.00883

MAGNUSSON, J., STROM, K., ROOS, S., SJOGREN, J., \& SCHNURER, J.

2003. Broad and complex antifungal activity among environmental isolates of lactic acid bacteria. FEMS Microbiol. Lett.219:129-135.

MEENA, K. R., \& KANWAR, S.S. 2015. Lipopeptides as the antifungal and antibacterial Agents: Applications in Food Safety and Therapeutics. BioMed Research International. Volume 2015, Article ID 473050, 9 pages. http://dx.doi.org/10.1155/2015/473050

MUNIMBAZI, C. \& BULLERMAN, L.B. 1998. Isolation and partia characterization of antifungal metabolites of Bacillus pumilus. J. Appl. Microbiol. 84:959-968. http://dx.doi.org/10.1046/j.1365-2672.1998.0043.x

NAIR, J.R., SINGH, G., \& SEKAR, V. 2002. Isolation and characterization of a novel Bacillus strain from coffee phyllosphere showing antifungal activity. $\mathrm{J}$. Appl. Microbiol. 93:772-780. $\quad$ http://dx.doi.org/10.1046/j.13652672.2002.01756.x

NAKAMURA, D., KAKIUCHI, K., KOGA, K., AND SHIRAI, R. (2006) Design and synthesis of novel c2-symmetric chiral piperazines and an application to asymmetric acylation of sigma-symmetric 1,2-diols. Org. Lett. 8, 6139-6142. http://dx.doi.org/10.1021/o10626387

OYEDELE, A. O., \& OGUNBANWO, T.S. 2014. Antifungal activities of Bacillus subtilis isolated from some condiments and soil. African Journal of Microbiology Research

http://dx.doi.org/10.5897/AJMR2013.6162

8(18):1841-1849.

PLEBAN, S., CHERMIN, L., \& CHET, I. 1997. Chitinolytic activity of an endophytic strain of Bacillus cereus. Lett in Appl. Microbiol. 25:284-288. http://dx.doi.org/10.1046/j.1472-765X.1997.00224.x/pdf

QAZI, J.I., QAISER, N., \& BANO, A.S. 2009. Isolation of antifungal bacteria from soil samples. Mycopath. 7(1):5-10.

RHEE, KI-HYEONG. 2003. Purification and identification of an antifungal agent from Streptomyces sp. KH-614 antagonistic to rice blast fungus, Pyricularia oryzae. J. Microbiol. Biotechnol. 13(6), 984-988.

STARK, T., AND HOFMANN, T. (2005). Structures, sensory activity, and dose/response functions of 2,5-diketopiperazines in roasted cocoa nibs (theobroma cacao). J. Agr. Food Chem. 53, 7222-7231. http://dx.doi.org/ 10.1371/journal.pone.0050824

TAKAYANAGI, T., AJISAKI, K., TAKIGUCH, Y. \& SHIMAHARA, K. 1991 Isolation and characterization of thermostable chitinases from Bacillus licheniformis X-7u. Biochimica et Biophysica Acta 1078:404-410. http://dx.doi.org/10.1016/0167-4838(91)90163-T

TENDULKAR, S.R., SAIDUMARI, Y.K., PATEL, V., RAGHOTAMA, S., MUNSHI, T.K., BALARAM, P., \& CHATTOO, B.B. 2007. Isolation, purification and characterization of an antifungal molecule produced by Bacillus licheniformis $\mathrm{BC} 98$, and its effect on phytopathogen Magnaporthe grisea. J of Appl Microbiol. 103:2331-2339. http://dx.doi.org/10.1111/j.13652672.2007.03501.x

TRACHUK, L.A., REVINA, L.P., SHEMYAKINA, T.M., CHESTUKHINA, G.G., \& STEPANOV, V.M. 1996. Chitinases of Bacillus licheniformis B-6839: isolation and properties. Canadian J of Microbiol. 42:307-315.

WATANABE, T., OYANAGI, W., SUZUKI, K., \& TANAKA, H. 1990 Chitinase system of Bacillus circulans WL-12 and importance of chitinase $\mathrm{A}_{1}$ in chitin degradation. J. Bacteriol. 172:4017-4022.

XU ZHIHUI, SHAO, J., LI, B., YAN, X., SHEN, Q., \& ZHANG, R. 2013 Contribution of Bacillomycin D in Bacillus amyloliquefaciens SQR9 to antifungal activity and biofilm formation. Appl and Environ Microbiol 79(3): 808 - 815. http://dx.doi.org/ 10.1128/AEM.02645-12

XIN ZHAO, ZHOU, Z., HAN, Y., WANG, Z., JIE FAN, J., \&_XIAO, H._ 2013. Isolation and identification of antifungal peptides from Bacillus BH072, a novel bacterium isolated from honey. Microbiological Research 168 (9):598-606. http://dx.doi.org/10.1016/j.micres.2013.03.001 